\title{
Temporal Distribution of Benthic Macroinvertebrate Communities from Tropical Forest Stream in Gunung Pulai Recreational Forest, Johor, Peninsular Malaysia \\ (Taburan Bermusim Komuniti Bentik Makroinvertebrat daripada Aliran Hutan Tropika di Hutan Rekreasi Gunung Pulai, Johor, Semenanjung Malaysia)
}

NOR ZAIHA A., MOHD ISMID M.S. \& SALMIATI*

\begin{abstract}
Temporal changes of Ephemeroptera, Plecoptera and Trichoptera (EPT) communities were investigated at the study area of Gunung Pulai Recreational Forest, Johor, Malaysia. Taxa diversity were also studied to determine the seasonality impact on certain benthic communities. Sampling of aquatic insects were carried out from November 2012 to July 2013 using rectangular dip net. As a result, more EPT were found during the dry season (1533 individuals) compared to wet season (321 individuals). Concomitantly, higher diversity was also recorded in the dry season. Among these three investigated orders, Trichoptera represented the most diverse community with three families recorded, followed by Plecoptera (2 families) and Ephemeroptera (1 family). Caddisfly family Hydropsychidae were found to be abundant in the study area. Therefore, seasonality impact on EPT assemblage at Gunung Pulai Recreational Forest is extremely evident.
\end{abstract}

Keywords: Benthic community; EPT; Gunung Pulai Recreational Forest; seasonal changes

ABSTRAK

Taburan bermusim bagi komuniti Ephemeroptera, Plecoptera dan Trichoptera (EPT) telah dikaji di kawasan kajian iaitu Hutan Rekreasi Gunung Pulai, Johor, Malaysia. Kepelbagaian takson turut dikaji untuk melihat sama ada terdapat kesan pengaruh musim terhadap komuniti bentik tertentu. Persampelan serangga akuatik telah dijalankan dari bulan November 2012 hingga Julai 2013 menggunakan jaring sauk berbentuk segi empat tepat. Hasilnya, lebih banyak EPT ditemui pada musim kering (1533 individu) berbanding musim hujan (321 individu). Pada masa yang sama, kepelbagaian takson turut direkodkan tinggi pada musim kering berbanding musim hujan. Antara ketiga-tiga order yang dikaji, Trichoptera diwakili oleh komuniti pelbagai dengan tiga famili dilaporkan, diikuti oleh Plecoptera (2 famili) dan Ephemeroptera (1 famili). Lalat kandul daripada famili Hydropsichidae didapati lebih banyak di kawasan kajian. Oleh yang demikian, pengaruh musim terhadap komuniti EPT di Hutan Rekreasi Gunung Pulai adalah sangat jelas.

Kata kunci: EPT; Hutan Rekreasi Gunung Pulai; komuniti bentik; perubahan musim

\section{INTRODUCTION}

Stream communities are shaped by environmental influences at multiple spatial scales. Their distribution, interaction and adaptation can be influenced by abiotic factors which vary in space and time (Bispo \& Oliveira 2007; Bispo et al. 2006; Cobb et al. 1992; Corkum 1990; Goldsmith 2007; Kittelson 2004; Morais et al. 1999; Tate $\&$ Heiny 1995). Climate is one of the factors that influence population dynamics of aquatic insects apart from other abiotic factors (Hynes 1970; Torres \& Madi-Ravazzi 2006; Wolda 1978). Few studies have related the seasonal changes in community structure with changes in the environment (Giller \& Twomey 1993). Seasonal pattern on the benthic community have been monitored in association with the changes in environment and as invertebrates move through their life cycles (Bothwell \& Culp 1993; Boulton \& Lake 1992; Hynes 1970).

Similar study was also conducted in the tropics because of uncertainty seasonal temperature setting is relatively small compared with temperate and subtropical regions (Che Salmah et al. 2001; Jongkar 2000; Lu 2005; Suhaila et al. 2014). In tropical regions, rainfall varies considerably throughout the year (Flecker \& Feifarek 1994). Rainfall increases current flow in mountainous areas. Rapid response in the headwater stream could change from quiet, trickling streams to torrents in an hour or two (Payne 1986). Therefore, the seasonal rainfall play an important role in influencing the temporal distribution of aquatic insect communities in these regions (Boon et al. 1986).

There are several groups of aquatic insects which are sensitive to environmental interference and can only survive in clean and oxygen-rich waters. Among them are Ephemerotera, Plecoptera and Trichoptera (ЕPT) assemblages which are easily found in low and medium stony cobble stream. Therefore, they are often considered as good indicators of water quality (Rosenberg \& Resh 1993). This study discusses how climate change affects the abundance and taxonomic benthic communities as 
well as the dominant species in a habitat of the river. EPT species were chosen because it reflects the overall ecology of benthic communities.

\section{MATERIALS AND METHODS}

\section{STUDY AREA}

This study was conducted in a recreational forest located in the state of Johor, southern Peninsular Malaysia (Figure 1). The sampling points are situated at latitude $01^{\circ} 35^{\prime} 25.6^{\prime \prime}$ $01^{\circ} 35^{\prime} 22.7^{\prime} \mathrm{N}$ and $103^{\circ} 31^{\prime} 01.1^{\prime \prime}$ - 103'30'54.2'E. Gunung Pulai Recreational Forest which is located in Gunung Pulai Forest Reserve is a classic lowland and hill Malayan dipterocarp forest on granite-based soil with the highest peak of the mountain is about $700 \mathrm{~m}$ above sea level. In addition to its function as water catchments and water supply to Singapore in the recent past, this area serves as habitat and protection of biodiversity, tourism, research and education.

\section{EPT SAMPLING}

Ephemeroptera, Plecoptera and Trichoptera (EPT) were collected over six sampling dates between November 2012 and July 2013 using rectangular dip net. The sampling methods were based on USEPA Rapid Bioassessment Protocol (RBP) multihabitat approach. Identification were made to the lowest practical taxonomic level, usually genus level based on Yule and Yong (2004) key taxonomic using stereo microscopre with 40 times magnification.

\section{DATA RESOURCES}

Monthly rainfall data from the nearest station was obtained from the Department of Drainage and Irrigation, Malaysia (DID). Based on the statistics of annual rainfall in 2013 by the Malaysian Meteorological Department, the average annual precipitation observed in the Senai meteorological station for the year was 2,876.40 mm with a minimum reading of $113.24 \mathrm{~mm}$. Malaysian Meteorological Department divides the southern state of Johor to the dry and wet seasons based on the amount of rain collected. Precipitation of less than $200 \mathrm{~mm}$ per month was considered as dry month and vice versa. The period of November to February representing the wet season, while April to July representing the dry season (Figure 2).

\section{DATA ANALYSIS}

The nonparametric Mann-Whitney U test was chosen in this study due to small data sample and not normally distributed. It is used to determine the effect of seasonality on the abundance and diversity of dominant species using SPSS (Statistical Package for Social Science) version 16®. Species diversity and evenness were also measured using ecological index Shannon-Wiener (H') dan Pielou (E), in both seasons.

\section{RESULTS AND DISCUSSION}

Overall, the abundance and diversity of EPT found changed throughout the study period. The sampling of EPT resulted in a total of 1584 individuals belonging to six genera and

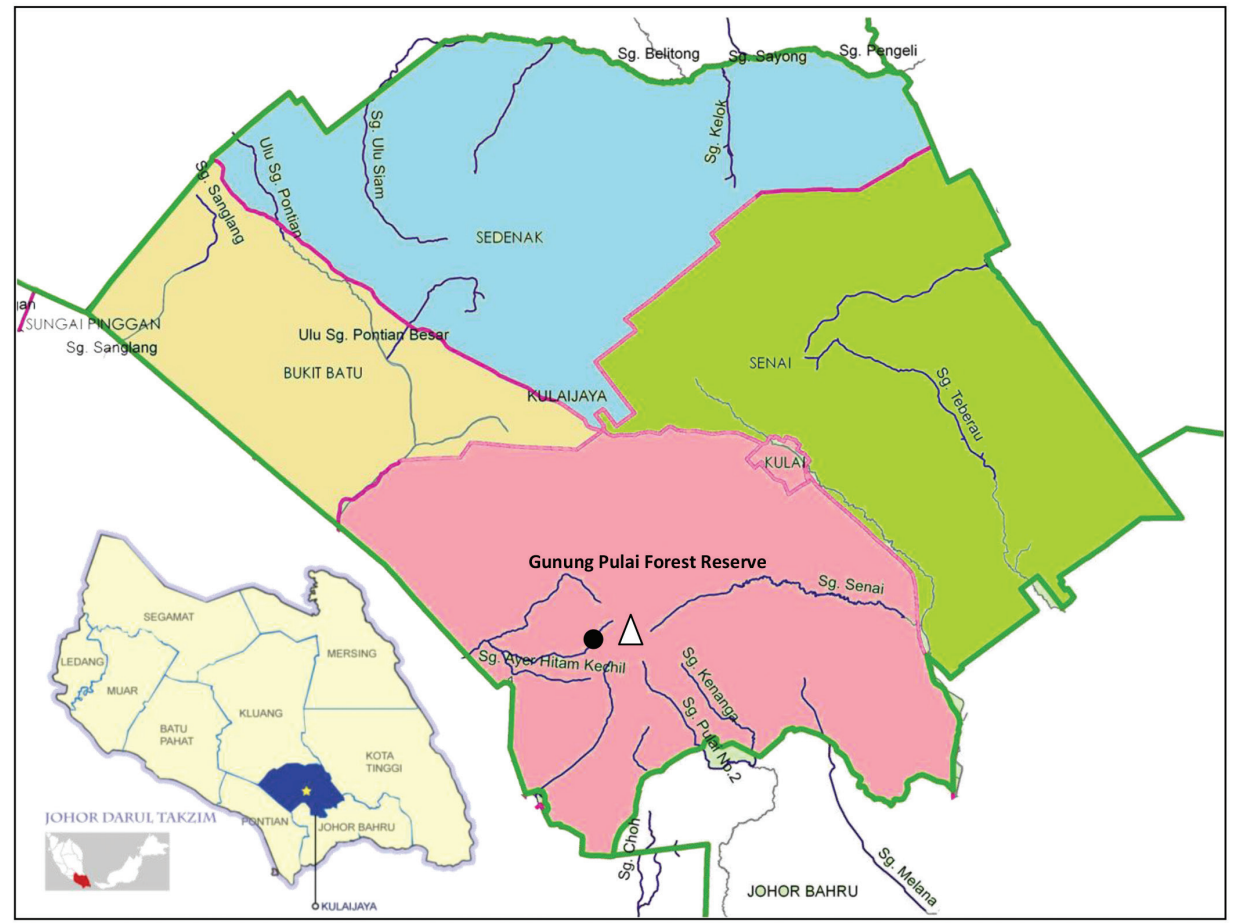

FIGURE 1. Location of the study area and EPT sampling station in Gunung Pulai Recreational Forest, Johor, Malaysia 


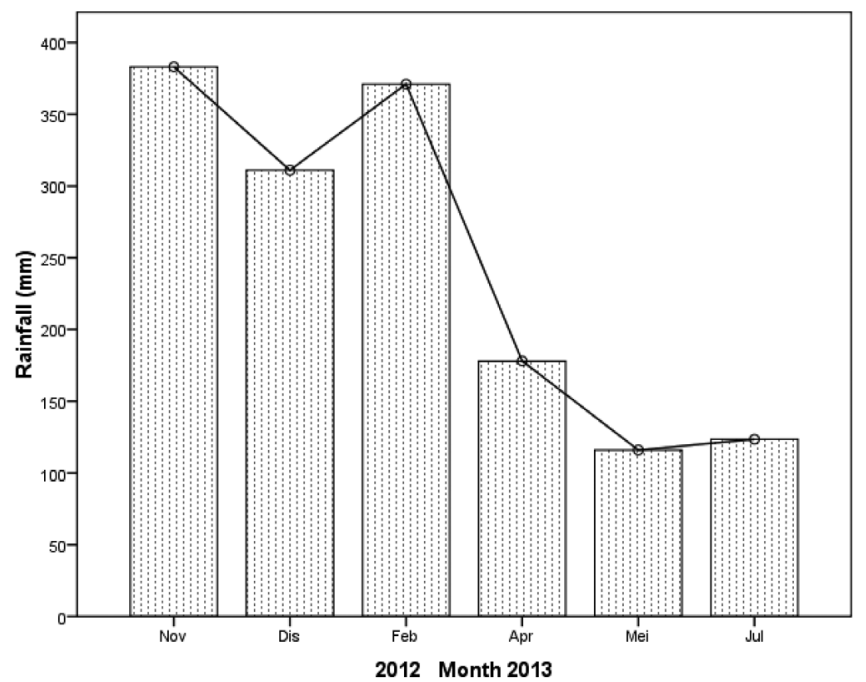

FIGURE 2. Monthly precipitation from November 2012 to July 2013 from the nearest rainfall station provided by Department of Drainage Malaysia

families. The highest mean abundance was recorded in the dry season with 511 individuals/ sample compared to the wet season, which was 107 individuals/ sample (Figure 3). Similarly, the highest mean value of diversity found in the dry season ( 5 taxa) compared with three taxa were recorded in the rainy season. This study is in line with the findings by Suhaila et al. (2012). The study led in Tupah River discovered that abundance and diversity of adult EPT assemblage changed seasonally. Among the three targeted groups, caddisfly families were the most pervasive. All of the ecological index values (ShannonWeiner and Pielou) were higher in the dry season (Figure 4 ). The mean value of diversity and evenness indices obtained in accordance with the number of species. Based on Table 1, a total of 6 EPT genus were found in Gunung Pulai Recreational Forest, i.e. Epeorus (Ephemeroptera: Heptageniidae) (5.34\%), Indonemoura (Plecoptera:
Nemouridae) (23.62\%), Neoperla (Plecoptera: Perlidae) (32.36\%), Hydropsyche (Trichoptera: Hydropsychidae) (37.06\%), Setodes (Trichoptera: Leptoceridae) (1.13\%) and Limnephilus (Trichoptera: Limnephilidae) (0.49\%). Compared to others, genus Hydropsyche (Trichoptera: Hydropsychidae) was the most prevalent taxa found. Figure 5 shows the distribution pattern of EPT during the study period. The abundance of main species perceived differently in each month. However, there are similarities among the graf whereby their populations are sharply increased as season progressed. The EPT populations peaked during the first phase of the dry season in April 2013.

Mayfly highest abundance was recorded in July 2013 (dry season) and the second highest occurred in the same season i.e. April 2013, with a cumulative total of 72 individuals. In this study, only one Mayfly family
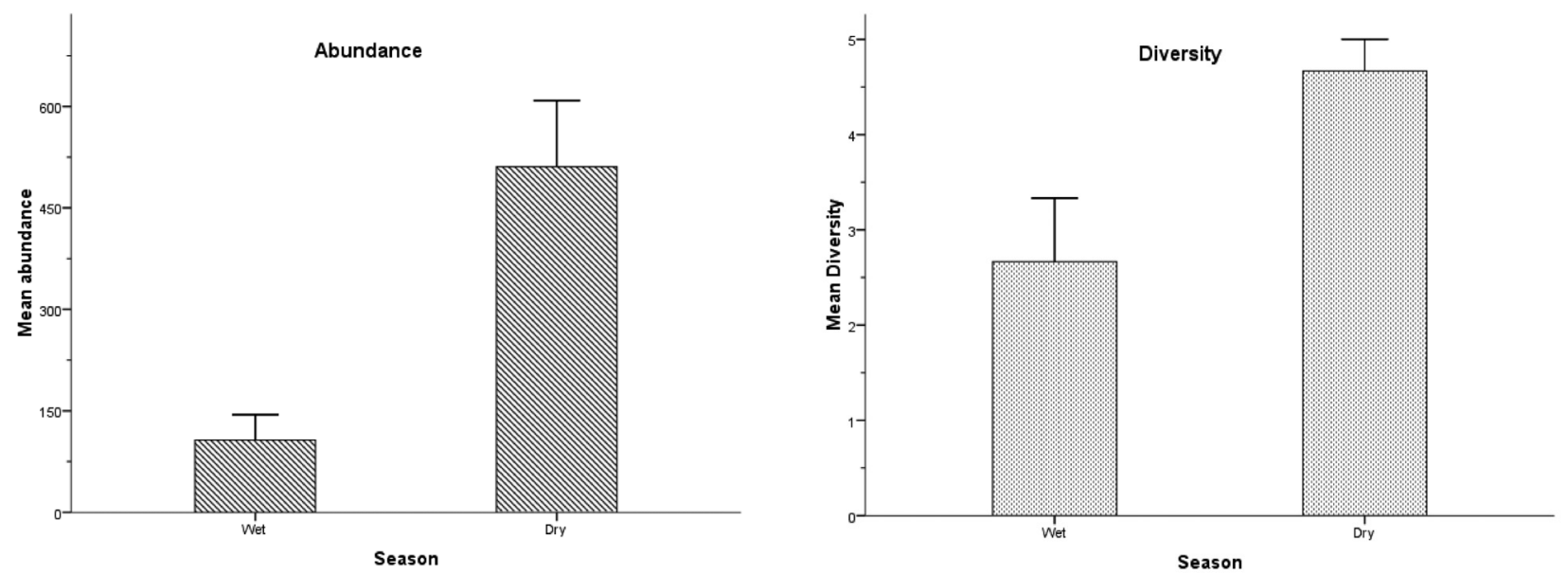

FIGURE 3. Temporal changes in the abundance and diversity of EPT during the study period (mean \pm SE) 


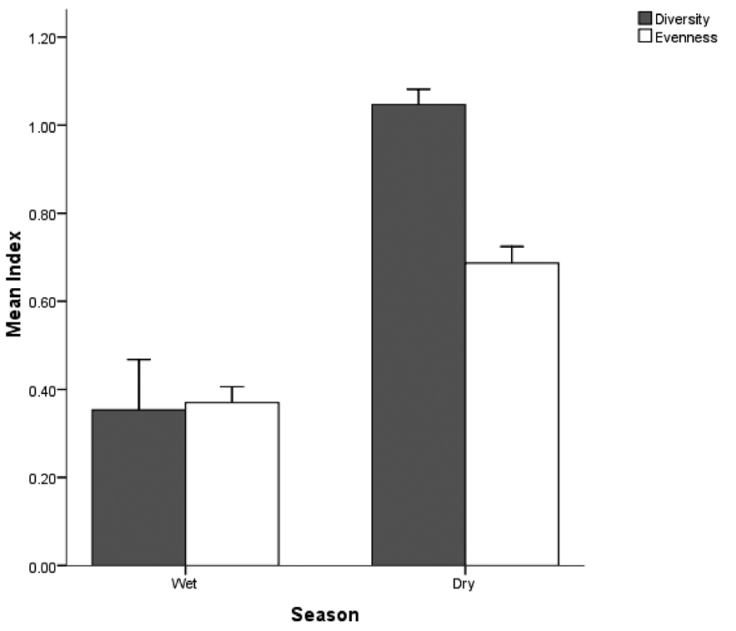

FIGURE 4. Temporal changes in diversity and evenness index of EPT during the study period (mean $\pm \mathrm{SE}$ )

TABLE 1. Mean abundance ( \pm standard error) of Ephemeroptera, Plecoptera and Trichoptera sampled from Gunung Pulai Recreational Forest from November 2012 to July 2013; $n=6$

\begin{tabular}{lllc}
\hline Taxa & & Mean abundance $\pm \mathrm{SE}$ \\
\hline Ephemeroptera & Heptageniidae & Epeorus & $16.50 \pm 6.83$ \\
Plecoptera & Nemouridae & Indonemoura & $73.00 \pm 32.67$ \\
& Perlidae & Neoperla & $100.00 \pm 41.85$ \\
Trichoptera & Hydropsychidae & Hydropsyche & $114.50 \pm 60.15$ \\
& Leptoceridae & Setodes & $3.50 \pm 0.92$ \\
& Limnephilidae & Limnephilus & $1.50 \pm 1.50$ \\
\hline
\end{tabular}
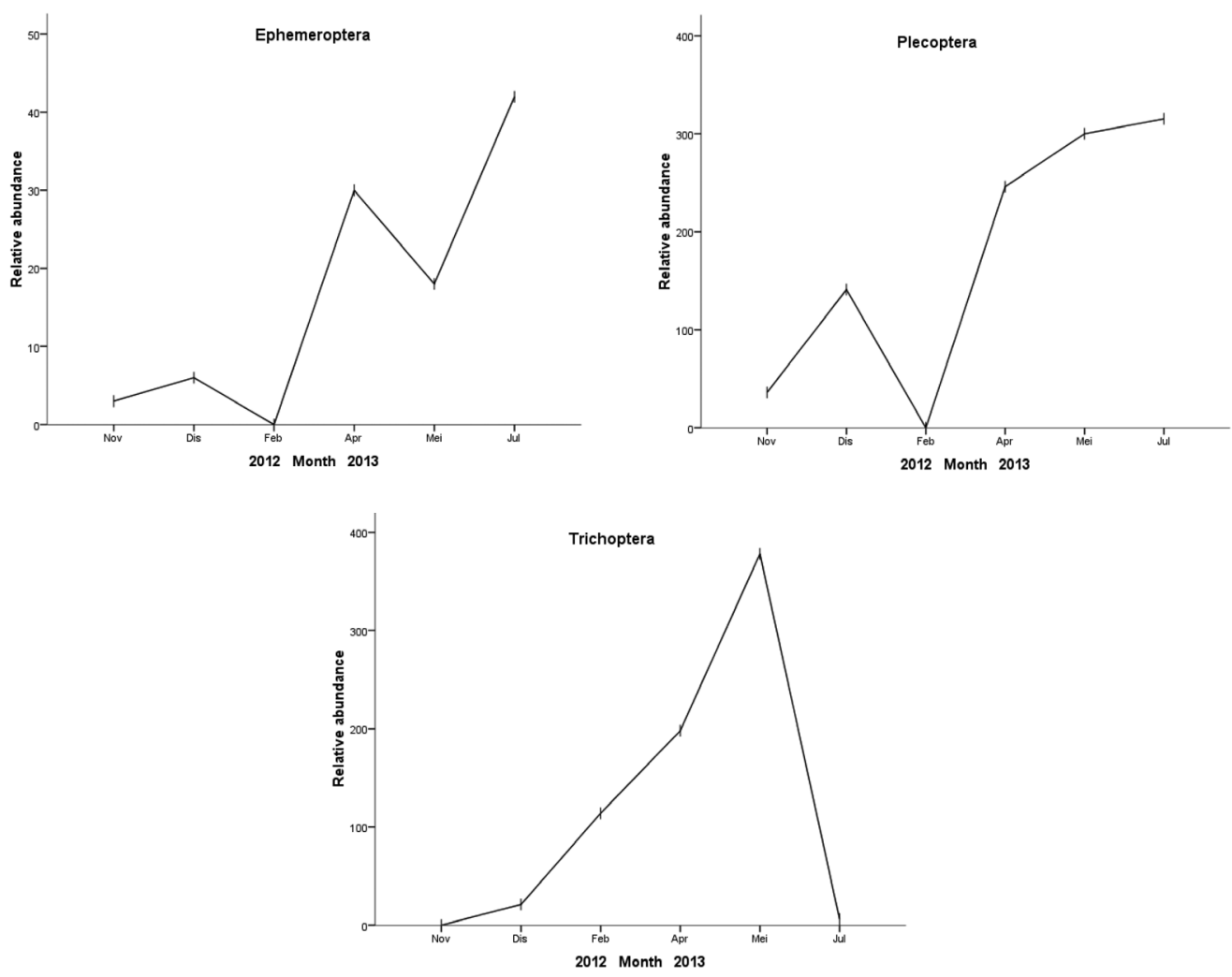

FIGURE 5. Monthly variation pattern of Ephemeroptera, Plecoptera and Trichoptera species during the study period 
recorded namely Heptageniidae. This family tends to dominate the shallow waters with rocky substrates. Riparian arthropod predators such as birds and other vertebrates constitutes a threat to the abundance of aquatic insects including Mayfly larvae, as reported by Baxter et al. (2005), Murakami and Nakano (2001) and Paetzold and Tockner (2005). In addition, the presence of high amounts of organic matter such as suspended materials during summer favored by some genera EPT to thrive in the environment (Suhaila et al. 2011). MannWhitney $U$ test found there was a significant difference in the distribution of Ephemeroptera in both seasons $(\mathrm{z}$ $=-1.964, p=0.05)$.

Plecoptera represented by two dominant families namely Nemouridae dan Perlidae. The highest population was recorded in the dry season, July and April 2013 (561 individuals) and the lowest population was in February 2013 where no insect was recorded. Based on Che Salmah et al. (2001), this type of insect fond of various sizes of rocks, debris and leaf packs as their habitat. High density of vegetative habitat provide leaf debris (allocthonous) as a food source for Stonefly insects (Bispo et al. 2006). Based on Mann-Whitney U test, there was a significant difference in the distribution of Plecoptera in both seasons $(\mathrm{z}=-1.964, p=0.05)$.

In contrast, Trichoptera exhibits the highest peak of abundance in the early of the dry period, but declined drastically. Trichoptera represents the percentage of the most abundant species (38.68\%) with the most dominant genus Hydropsyche. These kind of insects live in sheath made from organic debris and mineral fragments and makes the surface of the substrate as their habitat. Influence of rainfall within a certain period of the year resulted in environmental interference that contribute to the reduction of insect populations due to higher levels of rain water (Bispo \& Oliveira 2007). In addition, fast current or the movement of loose substrate can result in damage of the sheath and flushed away certain genera especially the free living genera that are less resistant to hydraulic stresses. The results of Mann-Whitney U test did not show significant difference of this species in both seasons $(\mathrm{z}=-1.091, p=0.275)$.

\section{CONCLUSION}

The present study indicates that tropical forest stream at Gunung Pulai Recreation Forest supported high diversity and abundance of EPT insects. The seasonal effect on EPT abundance were remarkably seen. The dry season condition was favourable to these investigated taxa as their abundance and diversity were higher during the dry season (April - July 2013). These constituents may be due to dry season offers an optimum environment for them to emerge, mate and oviposit, while the decrease in their abundance during the wet season due to the sudden increased in flow caused stream bed translocation, with the resultant removal of insects.

\section{ACKNOWLEDGEMENTS}

We are pleased to acknowledge the Ministry of Education Malaysia (Grant no. R.J130000.7809.4L830) and Universiti Teknologi Malaysia (UTM) on the grants awarded. Millions of thanks also goes to the staff of the Environmental Engineering Laboratory (MKAS) for their assistance in carrying out field work and laboratory.

\section{REFERENCES}

Baxter, C.V., Fausch, K.D. \& Saunders, W.C. 2005. Tangled webs: Reciprocal flows of invertebrate prey link streams and riparian zones. Freshw. Biol. 50(2): 201-220.

Bispo, P.C. \& Oliveira, L.G. 2007. Diversity and structure of Ephemeroptera, Plecoptera and Trichoptera (Insecta) assemblages from riffles in mountain streams of Central Brazil. Revista Brasileira de Zoologia 24: 283-293.

Bispo, P.C., Oliveira, L.G., Bini, L.M. \& Sausa, K.G. 2006. Ephemeroptera, Plecoptera and Trichoptera assemblages from riffles in mountain streams of central Brazil: Environmental factors influencing the distribution and abundance of immatures. Brazilian Journal of Biology 66: 611-622.

Boon, P.J., Jupp, B.P. \& Lee, D.G. 1986, The benthic ecology of rivers in the Blue Mountains (Jamaica) prior to construction of a water regulation scheme. Arch. Hydrobiol./Suppl. 74: 315-355.

Bothwell, M.L. \& Culp, J.M. 1993. Sensitivity of the Thompson River to Phosphorus: Studies on Trophic Dynamics. Saskatoon: National Hydrology Research Institute.

Boulton, A.J. \& Lake, P.S. 1992. The ecology of two intermittent streams in Victoria, Australia. III. Temporal changes in faunal composition. Freshwater Biology 27: 123-138.

Che Salmah, M.R., Amelia, Z.S. \& Abu Hassan, A. 2001. Preliminary distribution of Ephemeroptera, Plecoptera and Trichoptera (EPT) in Kerian River Basin, Perak, Malaysia. Pertanika Journal Tropical Agriculture and Science 24: 101-107.

Cobb, D.G., Galloway, T.D. \& Flannagan, J.F. 1992. Effects of discharge and substrate stability on density and species composition of stream insects. Canadian Journal of Fisheries and Aquatic Science 49: 1788-1795.

Corkum, L.D. 1990. Intrabiome distributional patterns of lotic macroinvertebrate assemblages. Canadian Journal of Fisheries and Aquatic Science 47: 2147-2157.

Flecker, A.S. \& Feifarek, B. 1994. Disturbance and temporal variability of invertebrate assemblages in two Andean streams. Freshwater Biology 31: 131-142.

Giller, P.S. \& Twomey, H. 1993. Benthic macroinvertebrate community organisation in two contrasting rivers: Betweensite differences and seasonal patterns. In Biology and Environment: Proceedings of the Royal Irish Academy. Royal Irish Academy. pp. 115-126.

Goldsmith, S. 2007. Density of longhorned beetles (Coleoptera: Cerambycidae) differs at different elevations in hawaiian montane forest. The Southwestern Naturalist 52: 364-370.

Hynes, H.B.N. 1970. The Ecology of Running Waters. Toronto, Canada: University of Toronto Press.

Jongkar ak Grinang. 2000. Kepelbagaian serangga akuatik di sungai-sungai kawasan hutan tadahan empangan Temenggor, Perak. MSc Tesis. Universiti Sains Malaysia, Penang. (Unpublished). 
Kittelson, P.M. 2004. Sources of variation in insect density on Lupinusarboreus sims: Effects of environment, source population and plant genotype. The American Midland Naturalist 152: 323-335.

Lu, L. 2005. Seasonal variation of macrobenthic infauna in the Johor Strait, Singapore. Aquatic Ecology 39(1): 107-111.

Morais, H.C., Diniz, I.R. \& Silva, D.M.S. 1999. Caterpillar seasonality in a central Brazilian cerrado. Revista de Biologia Tropical 47: 1025-1033.

Murakami, M. \& Nakano, S. 2002. Indirect effect of aquatic insect emergence on a terrestrial insect population through predation by birds. Ecol. Lett. 5(3): 333-337.

Paetzold, A. \& Tockner, K. 2005. Effects of riparian arthropod predation on the biomass and abundance of aquatic insect emergence. J. N. Am. Benthol. Soc. 24(2): 395-402.

Payne, A.I. 1986. The Ecology of Tropical Lakes and Rivers. Chichester: John Wiley and Sons.

Rosenberg, D.M. \& Resh, V.H. 1993. Freshwater Biomonitoring and Benthic Macroinvertebrates. London: Chapman \& Hall, IX + p. 488

Suhaila, A.H., Salmah, C.M. \& Huda, N.A. 2014. Seasonal abundance and diversity of aquatic insects in rivers in Gunung Jerai Forest Reserve, Malaysia. Sains Malaysiana 43(5): 667-674.

Suhaila, A.H., Salmah, M.R.C.\& Al-Shami, S.A. 2012. Temporal distribution of Ephemeroptera, Plecoptera and Trichoptera (EPT) adults at a tropical forest stream: Response to seasonal variations. The Environmentalist 32(1): 28-34.

Suhaila Abdul Hamid, Che Salmah, M.R., Hamady, D., Abu Hassan, A., Tomomitsu, S., Fumio, M. \& Michael, B. 2011. Seasonal changes in mayfly communities and abundance in relation to water physico-chemistry in two rivers at different elevations in northern Malaysia. Wetland Science 9(3): 240-250.
Tate, C.M. \& Heiny, J.S. 1995. The ordination of benthic invertebrate communities in the South Platte River Basin in relation to environmental factors. Freshwater Biology 33: 439-454.

Torres, F.R. \& Madi-Ravazzi, L. 2006. Seasonal variation in natural populations of Drosophila spp. (Diptera) in two woodlands in the State of São Paulo, Brazil. Iheringia, Série Zoologia 96: 437-444.

Wolda, H. 1978. Seasonal fluctuations in rainfall, food and abundance of tropical insects. Journal of Animal Ecology 47: 369-381.

Yule, C. \& Yong, H. 2004. Freshwater Invertebrates of the Malaysian Region. Kuala Lumpur: Akademi Sains Malaysia.

Nor Zaiha A. \& Salmiati*

Center of Environmental Sustainability and Water Security (IPASA), RISE

Universiti Teknologi Malaysia

81310 Johor Bahru, Johor Darul Takzim

Malaysia

Mohd Ismid M.S. \& Salmiati*

Department of Environmental Engineering

Faculty of Civil Engineering, Universiti Teknologi Malaysia

81310 Johor Bahru, Johor Darul Takzim

Malaysia

*Corresponding author; email: salmiati@utm.my

Received: 12 March 2015

Accepted: 27 May 2015 